\title{
Article \\ The Characterization of the Materials Used by Gino Severini in his 20th C Wall Paintings at Semsales in Switzerland
}

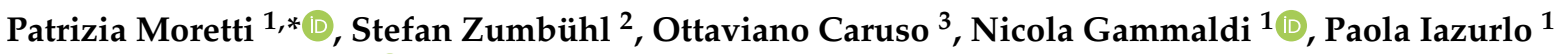 \\ and Francesca Piqué ${ }^{1, *(D)}$ \\ 1 Institute of Materials and Constructions, University of Applied Sciences and Arts of Southern \\ Switzerland (SUPSI), Via Flora Ruchat-Roncati 15, CH-6850 Mendrisio, Switzerland; \\ nicola.gammaldi@supsi.ch (N.G.); paola.iazurlo@supsi.ch (P.I.) \\ 2 Art Technological Laboratory HKB, Bern University of Applied Sciences, Fellerstrasse 11, \\ CH-3027 Bern, Switzerland; stefan.zumbuehl@hkb.bfh.ch \\ 3 Opificio delle Pietre Dure, Via degli Alfani 78, 50122 Firenze, Italy; ottaviano.caruso@gmail.com \\ * Correspondence: patrizia.moretti@supsi.ch (P.M.); francesca.pique@supsi.ch (F.P.)
}

Citation: Moretti, P.; Zumbühl, S.; Caruso, O.; Gammaldi, N.; Iazurlo, P.; Piqué, $\mathrm{F}$. The Characterization of the Materials Used by Gino Severini in his 20th C Wall Paintings at Semsales in Switzerland. Appl. Sci. 2021, 11, 9161. https://doi.org/10.3390/ app11199161

Academic Editor: Antonella Casoli

Received: 4 September 2021

Accepted: 26 September 2021

Published: 1 October 2021

Publisher's Note: MDPI stays neutral with regard to jurisdictional claims in published maps and institutional affiliations.

Copyright: () 2021 by the authors. Licensee MDPI, Basel, Switzerland. This article is an open access article distributed under the terms and conditions of the Creative Commons Attribution (CC BY) license (https:// creativecommons.org/licenses/by/ $4.0 /)$.

\begin{abstract}
The modern decoration of the Saint Nicolas de Myre Church at Semsales (1924-1926), is the first by renowned Italian artist Gino Severini in Switzerland. Following archival research and visual examination, the materials and the techniques used by Severini for the wall paintings of this church were examined through a multi-technique analytical approach that included both non-invasive and invasive investigations. Archival research revealed lists of some of the materials purchased for the church and notes of the artists. In situ investigations included imaging methods and point analyses (X-ray fluorescence and reflection FT-IR spectroscopy). Based on non-invasive results, a limited number of representative samples were collected for laboratory invasive analyses (SEM-EDS, FTIR-FPA imaging, $\mu$-Raman and GC-MS) to characterize the stratigraphy and the composition of the paintings. Results were coherent with artist's notes and revealed protein-based binders, i.e. animal glue and casein, exclusively on the Trinity mural (in the apse) confirming the use of $a$ secco technique. All the other wall paintings analyzed at Semsales are painted without the use of organic binders. These findings, integrated with archival researches and the visual examination by conservators, provided significant insights into the materials and techniques used by Gino Severini in his first Swiss murals.
\end{abstract}

Keywords: Gino Severini; Semsales; wall painting; a secco; a tempera; a fresco; organic binder; analytical investigation; non-invasive techniques; laboratory invasive methods

\section{Introduction}

In the Romand region of Switzerland, between 1924 and 1947, the well-known Italian artist Gino Severini (Cortona, 1883-Paris, 1966) decorated five churches in the context of a Catholic art renewal promoted by the Groupe de Saint-Luc [1,2]. Despite Severini's fame as cubist and futurist easel painting artist [3], his murals in Switzerland are not well known and have never been studied from the technical point of view. To fill this gap, a 4-year multidisciplinary research project (2018-2022) entitled "Gino Severini in Switzerland: mural paintings and Catholic art revival of the Groupe de Saint-Luc" is ongoing. This project is coordinated by the University of Applied Sciences and Art of Southern Switzerland (SUPSI), in collaboration with the Bern University of the Applied Sciences and the University of Lausanne [4,5]. Through an interdisciplinary approach that involves historical and archival research, visual examination, and scientific investigations, the project aims to provide a comprehensive and systematic study of the religious wall paintings by Gino Severini in Switzerland [6,7].

The first engagement of Severini in Switzerland was in 1924 for the decoration of the Church of Saint Nicolas de Myre at Semsales in the Canton Fribourg (Figure 1) [8]. Severini 
used different media to decorate this church: paintings on walls and on wood, mosaics, stone carving and ceramics. This research focused on the figurative wall paintings: the Trinity (in the apse), the Eucharist (in the presbytery), the monumental figures of Saint Nicolas and Saint Sebastian (on the north and south sides of the triumphal arch), the Virgin and Child and the Holy Family (on the end walls of aisles) (Figure 2). A thorough description of Severini's artistic processes provided by the technical examination of the wall paintings integrated with archival research is presented in Iazurlo et al. [9].
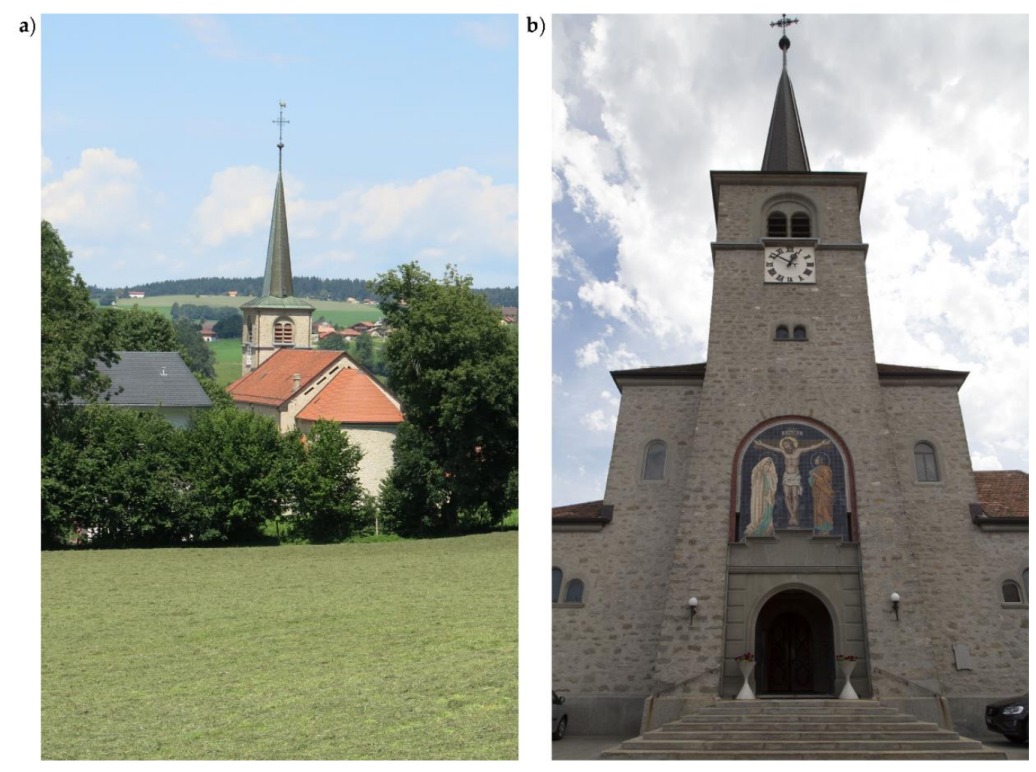

Figure 1. Exterior views of the Church of Saint Nicolas de Myre at Semsales in the Canton Fribourg. (a) Rural location of the church; (b) entrance with the Crucifixion in ceramic glazed tiles and carved stone portal by G. Severini.
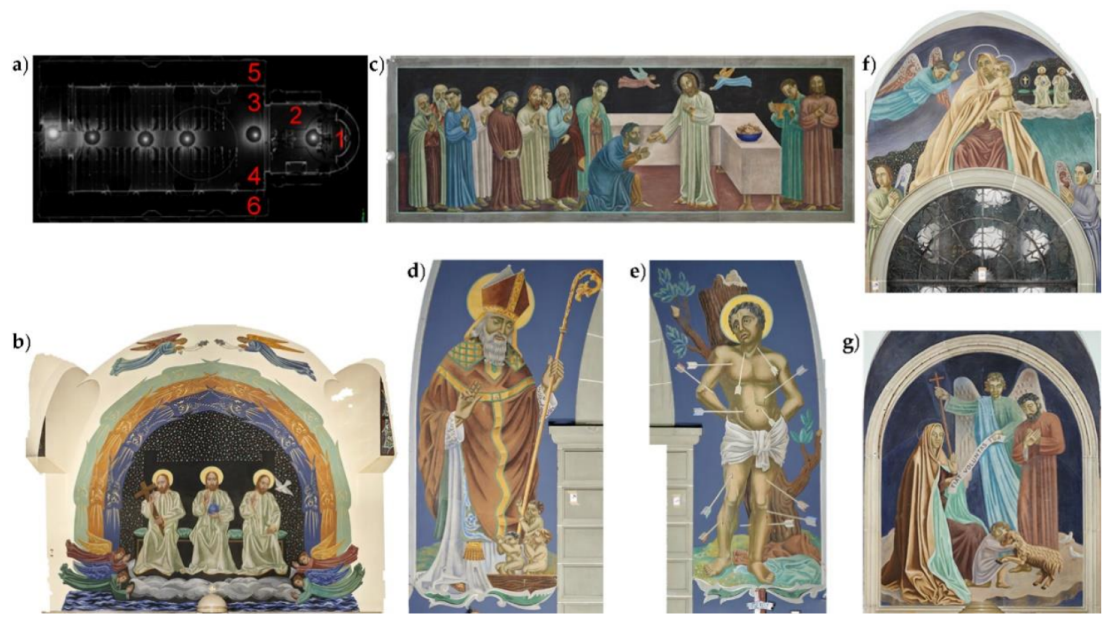

Figure 2. (a) Church plan with indication of the wall paintings' locations: 1 . Trinity $(6.7 \mathrm{~m} \times 5.6 \mathrm{~m})$ (b); 2. Eucharist $(6 \mathrm{~m} \times 2.2 \mathrm{~m})(\mathbf{c})$; 3. Saint Nicolas $(1.7 \mathrm{~m} \times 4 \mathrm{~m})(\mathrm{d}) 4$. Saint Sebastian $(1.7 \mathrm{~m} \times 4 \mathrm{~m})$ (e); 5. Virgin and Child $(2.5 \mathrm{~m} \times 1.8 \mathrm{~m})(\mathbf{f}) ; 6$. Holy family $(2 \mathrm{~m} \times 2.6 \mathrm{~m})(\mathrm{g})$. Orthophotos by Archéotech SA @SUPSI.

Severini was very interested in, and often adopted, the traditional and challenging a fresco technique to paint on walls. Strictly speaking, this technique does not involve the use of organic binders, but pigments are bound by the process of carbonation of a freshly applied lime plaster patch (giornata). To paint $a$ fresco requires practice, skills and often artists would complete their works by painting portions $a$ secco, i.e., after the lime plaster has set and using an additional binder: either lime, an organic material such as 
oil, animal glue, casein, egg or a mixture of these, or in combination. On wall paintings, organic materials are usually added in small amounts and are the hardest to identify as compared to the inorganic ones. At the same time, they are the materials most susceptible to deterioration and alteration.

The background archival research clearly indicated that although Severini preferred the a fresco technique, he was forced to decorate the apse of the Semsales church a secco because of the presence of a pre-existing gypsum-based plaster. Severini writes: “ ... L'enorme volta, che copriva l'ambiente, era costituita da un amalgamo resistentissimo di gesso, colla e rena, chiamato "rabitz"; ma su questa superficie non si potevano stendere che colori a tempera.... cominciai il mio lavoro al Coro con una "Trinità" ispiratemi da quella dipinta da Fouquet nel "Libro d'Ore" di Chantilly. Dovetti dipingerla a tempera, perché i muri della volta erano in "rabitz" e non vi si poteva dipingere a fresco." [10]. Instead, he painted the other wall paintings either a fresco, with a lime-based technique, or both. The different paint technique used by Severini is associated with the condition of the paintings: either the a fresco, lime-based portions, or both are in excellent condition, while some deterioration is visible on the Trinity.

This article describes the results of the analytical investigations carried out to characterize the artist's materials and provides, in particular, information on the organic materials identified in the wall paintings at Semsales. The methodology adopted for the analytical research follows that developed in the OMWP project [11] and includes a strong integration of previously collected data from background bibliographical and archival research and from the visual examination work by wall painting experts. The analytical study begins with in situ investigations with non-invasive techniques followed by, and integrated with, laboratory invasive analyses on micro-samples. The data collected for each wall painting allowed obtaining a good understanding of the stratigraphy and of the chemical composition of the paint and plaster components (i.e., pigments, binders, fillers, additives and aggregates). Overall, most of the findings were coherent with Severini's notes and other archival information $[7,9,10,12,13]$.

The opportunity to analyze Severini's work in Semsales permitted us to obtain a set of information that, combined with the conservators' observations and the historical and archival documents, provided a full understanding of the materials and the technical painting process followed by the artist during this, his first mural experience, in Switzerland.

\section{Materials and Methods}

\subsection{Analytical Approach}

The cycle of Severini's wall paintings in Semsales was examined by the integrated use of both non-invasive and invasive analytical techniques. Firstly, in situ mapping investigations were performed by collecting images in macro- and micro-scale by imaging methods and digital microscopy, respectively. Specifically, the use of different radiations (Vis, UV and IR) and high magnifications (in the case of the digital microscope) allowed us to evaluate and compare optical behavior, such as the presence of UV-induced visible luminescence, the morphology and overlapping of the paint layers. The results of this mapping investigation, interpreted and combined with observation by wall painting conservators, guided a preliminary selection of the areas to be studied with non-invasive point analysis. In this study, point analyses were carried out by X-ray fluorescence and reflection infrared spectroscopy to determine elemental and molecular composition of the materials, respectively, on the six wall paintings examined (Figure 2). The data emerged from the non-invasive measurements and the hypothesis formulated permitted the development of a targeted sampling strategy. Considering that the purpose of the study is understanding the original painting technique, sampling focused on well-preserved areas. A set of 11 representative samples was collected and mounted in cross-sections to characterize the stratigraphic sequence of paint layers and analyze the components of each layer by invasive laboratory methods (optical microscopy, SEM-EDS, FTIR-FPA imaging and $\mu$-Raman). Gas chromatography/mass spectrometry (GC/MS) analyses of 
three selected micro-samples provided additional accurate information on the nature of the organic materials in the Trinity.

\subsubsection{Imaging Techniques}

Technical photography was performed using a modified Nikon D800 digital camera (inbuilt UV/IR block filter removed) equipped with a CMOS detector (FX format $36 \times 24 \mathrm{~mm}^{2}$ ) with 36.3 mega pixel nominal full range from 350 to $1000 \mathrm{~nm}$ (Nital certified/Profilocolore s.r.l.). On the Semsales wall paintings, a total of 36 set of images were collected as follows: 11 for the Trinity, 12 for the Eucharist, 2 for Saint Nicolas, 2 for Saint Sebastian, 5 for the Virgin and Child and 4 for the Holy family. Specifically, each set consists of 6 types of photographic recordings (Vis, Rak, IRr, UVr, UVL and VIL) acquired by modifying radiation source and filters as necessary (see Table 1 for radiation source and filters used).

Table 1. Description of the radiation source and filters for the different imaging methods and in parenthesis the abbreviation used in the text to indicate the type of image.

\begin{tabular}{ccc}
\hline Imaging Method & Radiation Source & Filters \\
\hline 1. Visible-reflected (Vis) & Flash SB-910 Nikon * & Hot mirror + UV /IR CUT \\
\hline 2. Raking light (Rak) & Flash SB-910 Nikon * & Hot mirror + UV /IR CUT \\
\hline 3. Infrared-reflected (IRr) & Flash SB-910 Nikon * & Kodak Wratten 87 \\
\hline $\begin{array}{c}\text { 4. Ultraviolet-reflected (UVr) } \\
\begin{array}{c}\text { 5. Ultraviolet-induced visible } \\
\text { luminescence (UVL) }\end{array}\end{array}$ & CR500 LED Madatec & $\begin{array}{c}\text { B + W 403 UV pass filter Hot } \\
\text { mirror Kolari }\end{array}$ \\
\hline $\begin{array}{c}\text { 6. Visible-induced infrared } \\
\text { luminescence (VIL) }\end{array}$ & LED visible & $\begin{array}{c}\text { Hot mirror Better Light UV } \\
\text { cut Schott KV418 }\end{array}$ \\
\hline${ }^{*}$ Flash modified by removal of covering filter. & IR Pass 850 nm \\
\hline
\end{tabular}

\subsubsection{Digital Microscopy}

The digital portable microscope used to collect micro-images of the painting surfaces with high magnification $(50 \times$ and $200 \times$ ) is a Dino-lite Premier AM4115T-FUW equipped with 4 white and 4 UV (375 nm) LED lights switched by software (DinoCapture 2.0).

\subsubsection{X-ray Fluorescence (XRF)}

XRF analyses (a total of 310 measurements) were carried out with the Niton XL3t 900 $\mathrm{X}$-ray spectrometer produced by Thermo Scientific. The instrument is equipped with an $\mathrm{X}$-ray tube (maximum voltage $50 \mathrm{kV}$ ), an Ag anode and a semiconductor detector Si-PIN which allows a resolution of $195 \mathrm{eV}$. Acquisition time was $30 \mathrm{~s}$. This instrumental set-up, with a sampling area of ca. $3 \mathrm{~mm} \varnothing$, is suitable for the detection of chemical elements with atomic number $Z \geq 16$ (from sulfur; $S$ ).

\subsubsection{Reflection FT-IR Spectroscopy}

Non-invasive infrared spectra (a total of 142 measurements) were acquired through the compact portable Bruker ALPHA II spectrophotometer. This instrument is equipped with a dedicated external reflectance module with specular optics $\left(22^{\circ} / 22^{\circ}\right)$ which allow contactless analyses. The system consists of a CenterGlow source, a RockSolid interferometer (with gold mirrors) and a temperature controlled DTGS detector. An integrated USB video camera provides the view of the sampling area of ca. $3 \mathrm{~mm} \varnothing$. The reflection FT-IR spectra were recorded in the spectral range of $8000-350 \mathrm{~cm}^{-1}$ (medium and partially near infrared region), with a resolution of $4 \mathrm{~cm}^{-1}$ and using an average of $186 \mathrm{scans}$ (few minutes of acquisition time). Background correction was performed employing a spectrum collected from a flat gold mirror. Data are shown as pseudo-absorption spectra $\left(\mathrm{A}^{\prime}=\mathrm{Log}\right.$ $(1 / R) ; R=$ reflectance). The use of a wide IR spectral range that includes NIR radiations 
allows obtaining the chemical composition not only at the surface, but also from deeper layers of the paintings.

\subsection{Invasive Methods}

\subsubsection{Optical microscopy}

For microscopy, the samples were cast in Araldit 2020 epoxy resin and polished with micro mesh polishing cloths. The optical examinations were performed with a Leica DM270M microscope. The examinations were carried out in bright field and dark field with crossed polarizers. UV fluorescence images were taken with long pass filters at 430 and $515 \mathrm{~nm}$.

\subsubsection{Scanning Electron Microscopy (SEM-EDS)}

SEM-EDS on cross-sections were carried out with a Zeiss EVO MA 10 scanning electron microscope (2014) coupled with a Thermo NORAN System 7 (2014) EDS system with a Peltier cooled ULTRADRY detector for energy dispersive spectrometry measurements. The measurements were performed with an acceleration voltage of $20 \mathrm{kV}$ and with an acquisition time of $60 \mathrm{~s}$.

\subsubsection{FTIR-FPA Imaging}

FTIR imaging was performed by a Bruker Hyperion 3000/Tensor 27 infrared spectrometer with a germanium attenuated total reflectance (ATR) crystal (diameter: $250 \mu \mathrm{m}$ ). The spectral resolution achievable with the Cassegrain optics (NA 0.6) and the ATR Ge-crystal (Ge: $\mathrm{nD} 4.0$ ) is between 0.6 and $2.5 \mu \mathrm{m}$. The pixel resolution with pixel binning was $1 \mu \mathrm{m}$, covering an area of $32 \times 32 \mu \mathrm{m}^{2}$. The measuring depth is approx. $0.2-0.7 \mu \mathrm{m}$ and the FT-IR spectra were recorded in the spectral range of $4000-900 \mathrm{~cm}^{-1}$, with a resolution of $4 \mathrm{~cm}^{-1}$ and using an average of 64 scans.

\subsubsection{Micro-Raman Spectroscopy}

The Raman spectroscopy measurements were performed using a Renishaw InVia (2007) system, with a $250 \mathrm{~mm}$ focal length. The maximum spectral resolution is $\sim 1-0.5 \mathrm{~cm}^{-1}$ achievable (depending on wavelength and grating). The system is coupled with 3 lasers; a $785 \mathrm{~nm}$ laser (diode-type): Renishaw HP NIR785 (300 mW), grating $1200 \mathrm{~L} / \mathrm{mm}$, edge filter, 110-3200 $\mathrm{cm}^{-1}$, a $633 \mathrm{~nm}$ laser (He-Ne-type): Renishaw RL633 (17 mW), grating $1800 \mathrm{~L} / \mathrm{mm}$, std edge filter, $100-4000 \mathrm{~cm}^{-1}$ and a $514 \mathrm{~nm}$ laser (Ar-type): Spectra-Physics $(24 \mathrm{~mW})$, grating $1800 \mathrm{~L} / \mathrm{mm}$, sup edge filter, $100-4000 \mathrm{~cm}^{-1}$. The spectra were acquired with different power and a spectral resolution of $2 \mathrm{~cm}^{-1}$. The measuring field size depends on the lens and the laser used. Normally (with $100 \times$ objective) this is approximately $1 \mu \mathrm{m}$. with a penetration depth of $2 \mu \mathrm{m}$.

\section{Results}

The results are presented in two sections following the known technical differences between the wall painting $a$ secco of the Trinity in the apse (Section 3.1) and either the $a$ fresco, lime-based wall paintings or in combination, in the rest of the church (Section 3.2).

In each section, the results are presented according to the investigation protocol, i.e., data from non-invasive investigations followed by those obtained by lab-analyses. Specifically, the non-invasive techniques provided information concerning the optical behavior (imaging methods) and the molecular composition (reflection FT-IR spectroscopy) of the surface paint materials. The chemical elements identified by XRF arise from the deeper layers too, but it is not possible to define their specific stratigraphic distribution. For this purpose, SEM-EDS and FTIR-FPA imaging analyses of micro-samples mounted in cross-sections were fundamental. Moreover, the examination of the cross-sections by both optical and scanning electron microscopy provided the aspect, color and morphology of each layer, as well as a better distinction between layers and the identification of thin intermediate layers. 
Overall, the set of information obtained from the non-invasive multi-technique analytical approach, verified and implemented by the study of the samples, allowed formulating a hypothesis about the paint composition and the process of execution of the murals. Generally, this interpretation process can lead to formulating different options and identifying questions to be addressed by future researches.

Although this paper focuses on Severini's original painting technique, some information is also provided on the materials identified for the limited retouching found on the paintings.

\subsection{The Trinity: A Secco Wall Painting}

The in situ non-invasive investigations on the Trinity mural promptly confirmed the $a$ secco nature of this wall painting as described by Gino Severini [10]. UV-induced visible luminescence images, as part of the imaging methods, showed intense luminescence in many wall painting portions (examples of Vis and UVL images of mural portions are shown in Figure 3a,b). Several optical behaviors could be observed, in particular UV-induced visible luminescence which could be attributed to both organic material and inorganic pigments, typically synthetic pigments [14]. For example, a very bright yellow-green UVL emission corresponding to white areas (Figure $3 b$ ) suggested the presence of zinc white $(\mathrm{ZnO})$. This was confirmed non-invasively by the XRF detection of zinc (Zn) (Figure S1) and with the molecular composition emerged from the in situ infrared analyses (Figure 3c). Zinc white was only identified in the painting of the Trinity at Semsales.

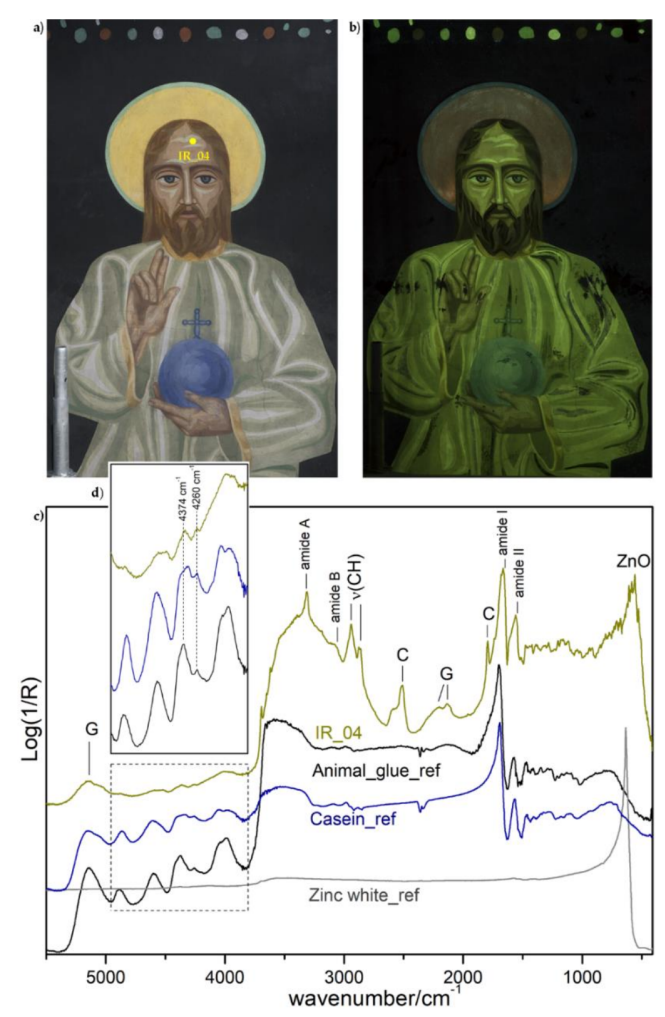

Figure 3. (a) Vis and (b) UVL images of the central figure (image size ca. $90 \mathrm{~cm} \times 90 \mathrm{~cm}$ ) of the Trinity shown in Figure $2 b$. The UV-induced visible luminescence in (b) is related to the presence of zinc white ( $\mathrm{ZnO})$ and cadmium-based pigments (Cd in the halo). (c) Reflection FT-IR spectrum collected from the point IR_04 (location shown in (a) in comparison with reference spectra of animal glue, casein and zinc white. Marker bands of calcium carbonate (C) and gypsum (G). (d) Magnification of the spectral range between ca. 3750 and $5000 \mathrm{~cm}^{-1}$ showing better match with the FT-IR spectrum of animal glue than with that of casein. 
Another group of luminescent pigments identified are cadmium-based yellow and orange (CdS). In this case, UV-induced visible luminescence appears bright red-orange [15] (see the halo of Christ in Figure $3 b$ ) and the presence of the element cadmium (Cd) was confirmed by XRF (Figure S1). Interestingly, in some orange areas the element mercury $(\mathrm{Hg})$ was found along with cadmium (Figure S2) suggesting the possible presence of a cadmium/mercury sulfide $\left(\mathrm{CdHgS}_{2}\right)$ pigment [16] or a mixture of cadmium yellow and vermilion (HgS). However, the exclusive use of vermilion is limited to a few specific red portions of the painting (e.g., lips of the central figure, Figure S2).

Overall, by combining the imaging data with the XRF and the FT-IR analysis it was possible to characterize Severini's palette in a completely non-invasive way. In addition to the already discussed materials, pigments identified include: ultramarine blue, chromebased green, ivory black, red/brown and black earths. Kaolinite and gypsum, probably used as fillers in the formulation of these iron-based pigments, were found by FT-IR in most of samples analyzed.

More detailed information on the chemical formulation of some pigments emerged from the invasive analysis of micro-samples. For example, chromium hydroxide green "Guignet green" was recognized by micro-FT-IR on a micro-sample coming from the background decoration (green dots). This pigment is a variation of viridian produced by calcination, as documented by the presence of the by-product chromium borate [17]. Moreover, on the Trinity dark background two different black pigments were found: ivory black on the homogenous base and an iron-rich black pigment (i.e., black earth) used for the retouches applied by Severini himself to modify the shape of some colored dots.

In several cases, UV-induced visible luminescence was linked to the presence of organic materials, i.e., the a tempera paint mentioned in Severini's unpublished manuscript [10]. Luminescence of organic material is attenuated by specific types of colors, blacks and dark browns, while others pigments (Cu-based) significantly reduce/eliminate the UV-induced visible luminescence [18]. However, FT-IR spectra confirmed the presence of organic material in all the 47 spectra acquired for the Trinity mural (a representative spectrum is shown in Figure 3c). The protein-based nature of the binder is suggested by detection of amide infrared bands at ca. 3313 (amide A), 3064 (amide B), 1658 (amide I) and 1565 (amide II) $\mathrm{cm}^{-1}$ [19]. Although, it is not possible to identify the type of protein exclusively by non-invasive FT-IR [20], a tentative assignment to an animal glue can be formulated considering the signals at ca. 4374 and $4260 \mathrm{~cm}^{-1}$ of the methylenic stretching and bending combination bands [21] (Figure 3d). However, the broad shape of the bands and the co-presence of other compounds makes the protein discrimination difficult. Gypsum and calcium carbonate present in either the plaster, preparatory layers or both (marker IR bands depicted with C and G, respectively, in Figure 3c) are among these interfering compounds.

The stratigraphic distribution of the compounds identified non-invasively, was examined through the study of micro-samples selectively taken from the mural and mounted in cross-sections. An example of the data set collected for a sample coming from the Trinity background is provided in Figure 4. Firstly, the microscope examination (Figure $4 \mathrm{~b}$ ) allowed the distinction of two preparatory layers characterized by different properties and morphological aspect as clearly visible in the SEM-BSE images (Figure 4c). The micro-FTIR measurements across the entire stratigraphy of the sample (Figure $4 \mathrm{~d}$ ) permitted the detection of gypsum exclusively in the plaster (layer 1) with a possible weak contribution of an organic material (carbonyl band between 1711 and $1750 \mathrm{~cm}^{-1}$ localized in a thin line of layer 1-Figure 4e). On the top of the gypsum-based plaster, the identification of amide I band (1695-1615 $\mathrm{cm}^{-1}$ ) suggested the presence of a primer (layer 2) composed of a proteinaceous material and followed by a lime-based preparatory layer (layer 3 ). In the latter, the weak protein component observed (Figure 4e) is probably penetrated from the upper protein bound paint layer (layer 4) containing ivory black (see phosphate group bands between 1061 and $992 \mathrm{~cm}^{-1}$ [22] in Figure 4e). A representative IR spectrum of layer 4 is shown in Figure S3. 

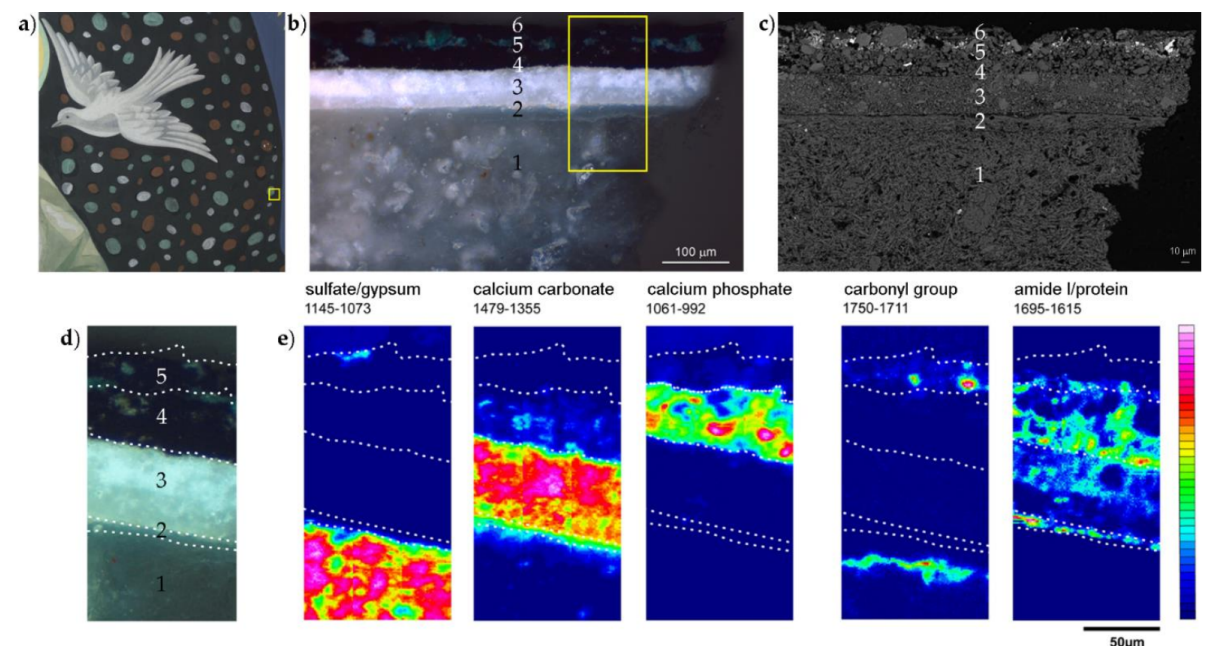

Figure 4. (a) Detail of the Trinity background (image size ca. $80 \mathrm{~cm} \times 80 \mathrm{~cm}$ ) with indication (yellow square) of the sampling area (black edge of a green dot); (b) optical microscope image and (c) SEMBSE image of the cross-section of the micro-sample collected in a; (d) cross-section area analyzed by FTIR-FPA imaging (the location is shown in $b$ with a yellow rectangle); (e) FTIR-FPA imaging results with integration of the following spectral range: $1145-1073 \mathrm{~cm}^{-1}$ (sulfate/gypsum), $1479-1355 \mathrm{~cm}^{-1}$ (calcium carbonate); 1061-992 cm-1 (calcium phosphate/ivory black); 1750-1711 cm-1 (carbonyl group); $1695-1615 \mathrm{~cm}^{-1}$ (amide I/protein).

Concerning the lime-based preparatory layers, it is important to point out that in the cross-sections obtained from two samples coming from the upper part of the vault, an additional yellow lime-based layer (Figure 5b, layer 4 ) is visible above the white lime-based layer (Figure 5b, layer 3). The yellow preparatory layer consists of a blend of yellow ochre and cadmium yellow mixed with calcium carbonate. The presence of cadmium yellow in this underlayer explains the element cadmium found in all the XRF spectra, a total of 39 spectra, acquired on the two angels in the upper part of the vault (Figure 2b), particularly where the color of the paint layer is a dark blue or black, i.e., not associable with a cadmium-based pigment. This yellow preparatory layer does not seem to be present in the rest of the Trinity. In the sample shown in Figure 5, over this yellow preparatory layer, the paint layer is visible in multiple applications (layer 5). The paint layers contain zinc white, yellow ochre, cadmium yellow, ivory black and an organic red pigment, all mixed with a protein-based binder. On the sample surface, the last layer (layer 6) is a non-original application of an acrylic resin. The cross-section shows that the yellow preparatory layer is broken and lifting, probably due to the application and the shrinkage upon drying of the acrylic surface coating.

Overall, high protein amounts were found in correspondence with the paint layer in each Trinity sample examined, confirming the data emerged from the in situ infrared investigations. Moreover, in addition to protein signals, most of the non-invasive FT-IR spectra contained the signal at ca. $1740 \mathrm{~cm}^{-1}$ related to carbonyl stretching mode and sharp $\mathrm{CH}$ bands between $3000-2700 \mathrm{~cm}^{-1}$ that suggest the possible presence of a lipid component. These infrared features were particularly pronounced in spectra acquired from areas with a different appearance in the UVL images. For example, in situ FT-IR on a cloud (Figure 6) revealed that this UVL difference could be related to an additional diluted paint or glaze application containing a lipid component. In order to identify the nature of this component and that of the protein-based binder, a micro-sample representative of the measuring point IR_42 (Figure 6b) was analyzed by gas chromatography/mass spectrometry (GC/MS). Regarding the proteins, GC/MS identified a mixture of animal glue and probably casein. The results did not help to clarify the lipid component as they revealed a diterpenoid resinous material such as pine resin, and excluded the presence of a siccative oil. These results, as well as the presence of small amounts of pine resin, 
were also confirmed by GC/MS analysis in the other two Trinity samples analyzed by this method, however, pine resin was in much higher amounts in the area of cloud identified by UVL [23].
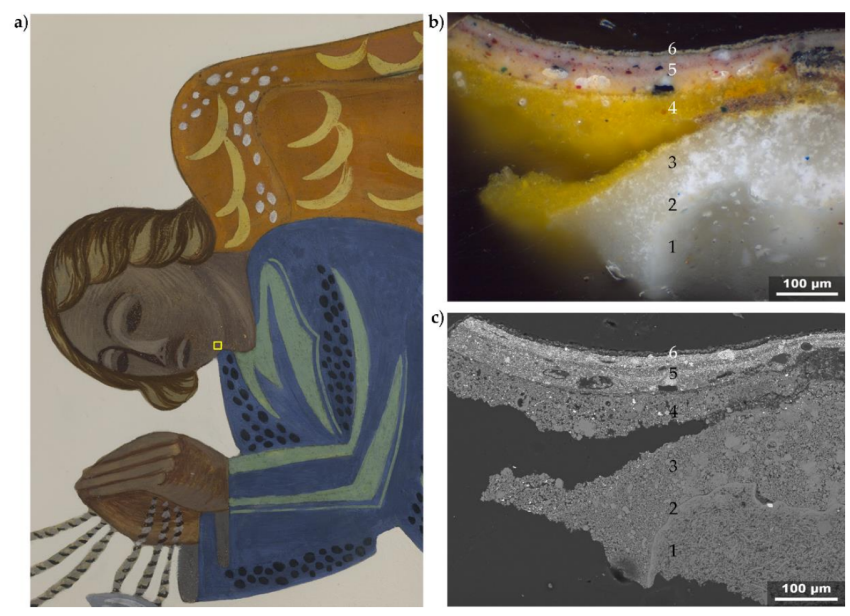

Figure 5. (a) Detail of one of the two angels (image size ca. $70 \mathrm{~cm} \times 100 \mathrm{~cm}$ ) above the Trinity in the south portion of the upper part of the vault with indication of the sampling area (yellow square); (b) optical microscope image and (c) SEM-BSE image of the cross-section of the micro-sample taken in the area shown in (a).
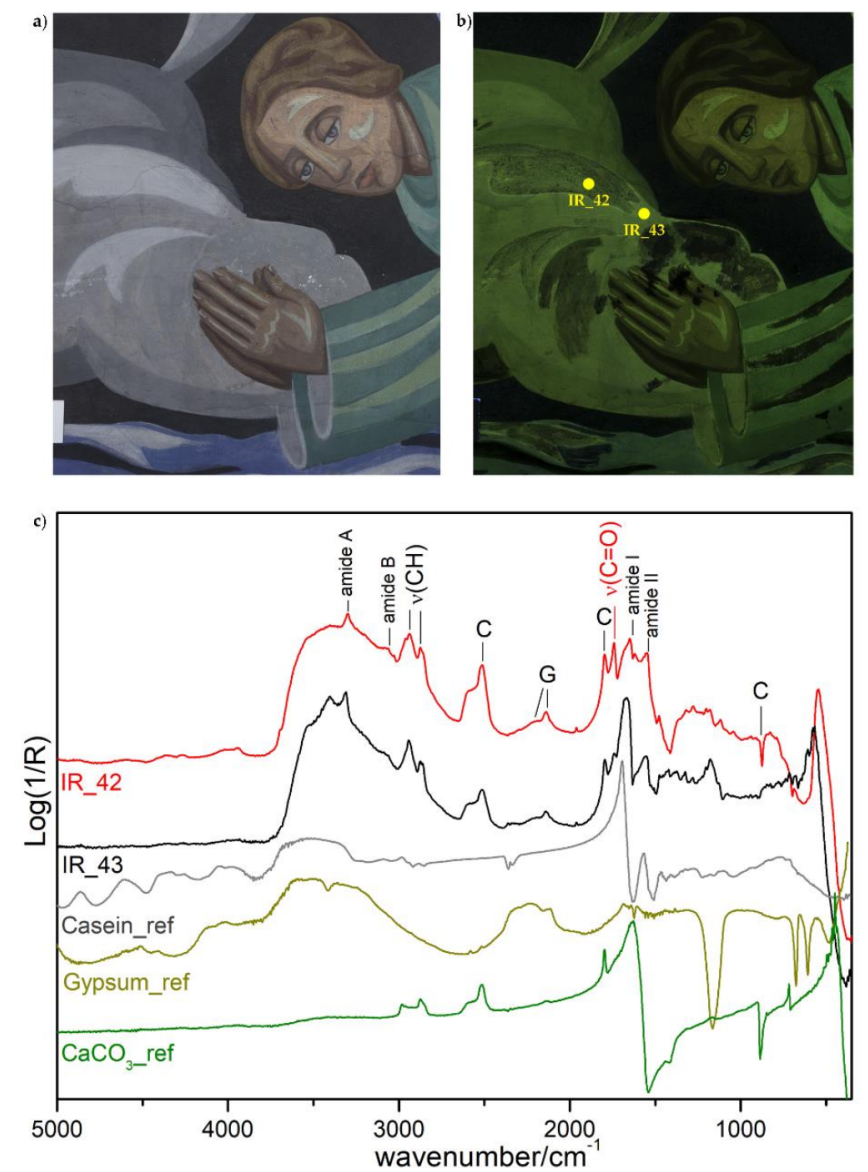

Figure 6. (a) Vis and (b) UVL images of a detail of cloud and angel (image size ca. $55 \mathrm{~cm} \times 70 \mathrm{~cm}$ ) in the lower south portion of the Trinity in the apse. (c) Reflection FT-IR spectra collected from the points IR_042 and IR_43 (location shown in (b) in comparison with reference spectra of casein, gypsum and calcium carbonate). Marker bands of calcium carbonate (C) and gypsum (G). 
Later addition, repainting and non-original areas were promptly recognized in the UVL images mainly for their lack of UV-induced visible luminescence. The element titanium (Ti) was detected exclusively in some of these repainted areas and similarly the synthetic resins identified, acrylic, styrene/n-butyl acrylate (Sty/n-BA) copolymer and vinyl, were all in non-original paint and coatings applications.

\subsection{A Fresco and/or Lime-Based Wall Paintings}

The analytical study of the Severini's murals in the presbytery (Eucharist), triumphal arch (Saint Nicolas and Saint Sebastian) and aisles (Virgin and Child and Holy Family) of the Semsales church confirmed that Severini painted in either the a fresco, lime-based technique, or both.

Optical and SEM-BSE microscope images of a sample taken from the Virgin and Child (Figure 7) show a typical stratigraphy of a lime-based painting consisting of a relatively thick paint layer (layer 2) on a plaster (layer 1) characterized by aggregates of different color, shape and size. SEM-EDS (Figure 7c) and FTIR-FPA imaging analyses (Figure S4) revealed the presence of calcium carbonate in the paint layer. In addition, the upper part of the plaster is visibly enriched in calcium carbonate (as a sinter layer, Figure S4). These morphological and chemical characteristics suggest a lime-based technique rather than $a$ fresco [24].
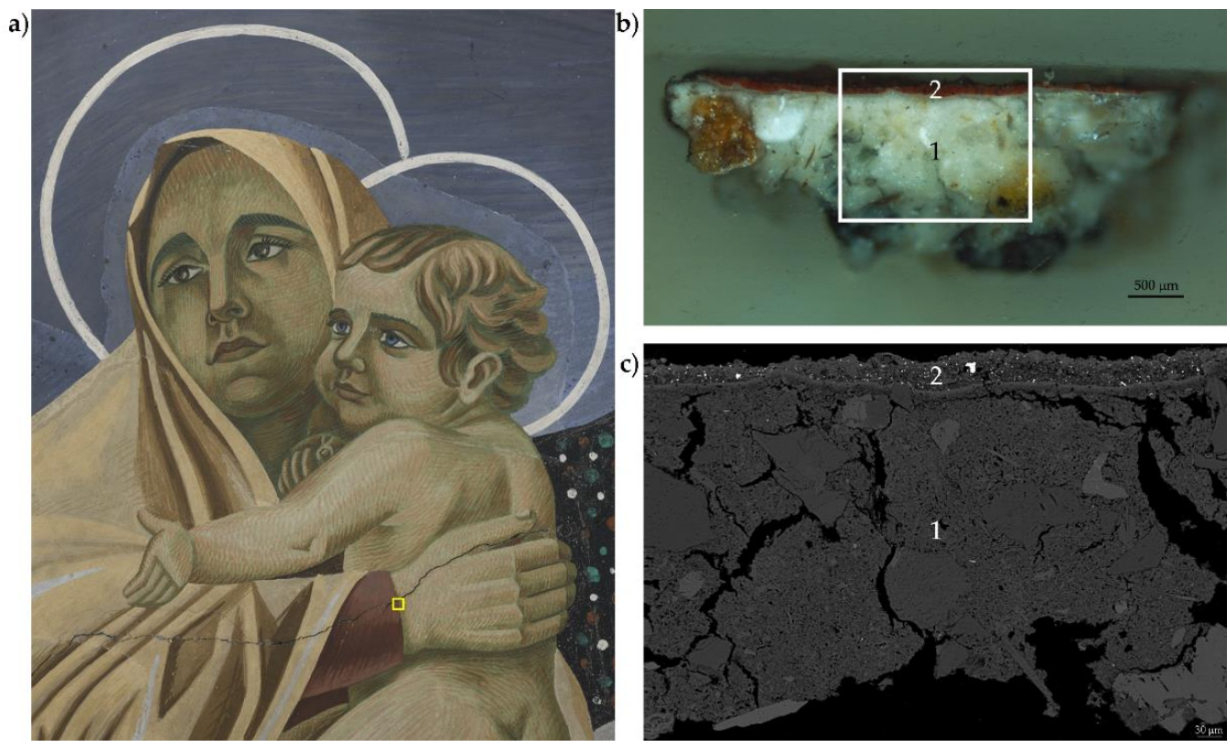

Figure 7. (a) Detail of the Virgin and Child (image size ca. $50 \mathrm{~cm} \times 60 \mathrm{~cm}$ ) with indication of the sampling area (yellow square); (b) optical microscope image and (c) SEM-BSE image of the crosssection of the micro-sample collected in (a). SEM-BSE image corresponds with the area indicated with a white rectangle in (b).

UVL images allowed us to hypothesize the presence of pigments such as Cd-based pigments, red lakes and also zinc white in small areas of retouching in the Eucharist mural. The floral decorations on the cloak and the crozier of Saint Nicolas showed a pink $\mathrm{UV}$-induced visible luminescence (Figure 8a,b) different from the orange one due to the presence of cadmium yellow (see also the visible-induced infrared luminescence showing the distribution of the cadmium yellow in Figure 8c). The white pigment used by Severini in these wall paintings was the Sangiovanni white $\left(\mathrm{CaCO}_{3}\right)$. In addition to the pigments detected in the Trinity, Severini added pigments commonly used and compatible with either the a fresco, lime-based technique, or both, such as green earth and yellow ochre. 


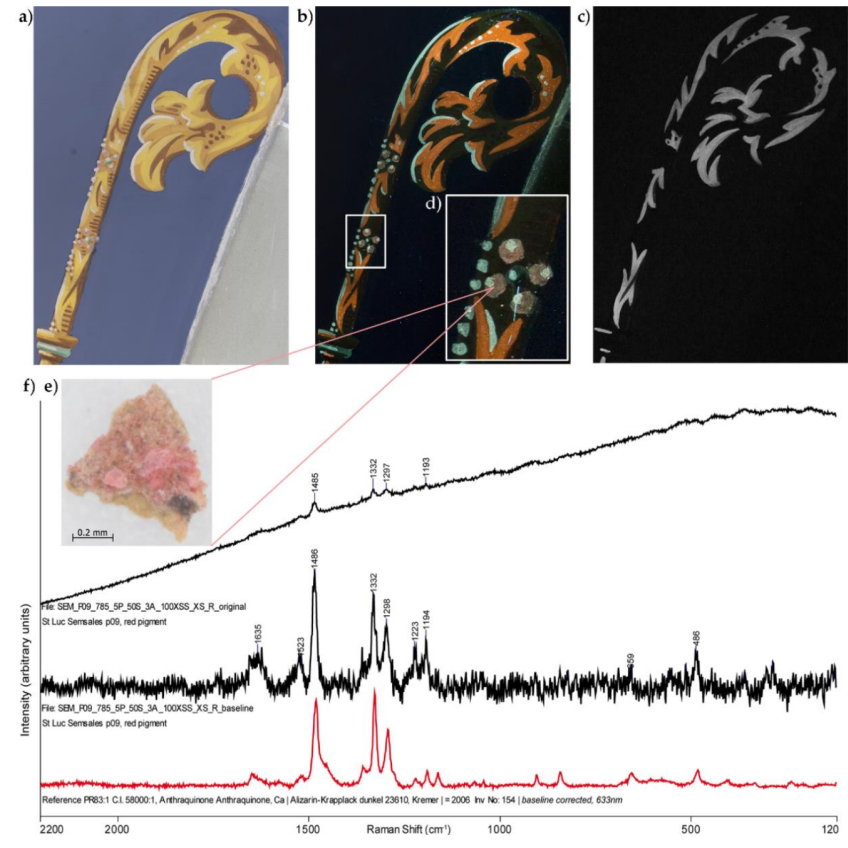

Figure 8. (a) Vis, (b) UVL and (c) VIL images of a detail of the crozier (image size ca. $50 \mathrm{~cm} \times 75 \mathrm{~cm}$ ) of Saint Nicolas; (d) sampling area on a pink portion of the flower; (e) micro-sample analyzed by micro-Raman; (f) Raman spectrum (original and with baseline correction) compared with a reference spectrum of synthetic alizarin lake (PR83).

The micro-Raman analysis performed on a micro-sample taken from a flower (Figure 8d,e) allowed the identification of bands at ca. 1486, 1332 and $1298 \mathrm{~cm}^{-1}$ (Figure 8f) ascribable to synthetic alizarin lake (PR83; 1,2-dihydroxyanthraquinone) $[25,26]$ on an aluminum phosphate substrate (Al and P identified by SEM-EDS analysis of the cross-section). The presence of alizarin lake can be correlated with the pink luminescence observed in the UVL image. Similar UVL color was also noticed in some of the flowers of the crown of the angel depicted in the Holy family (Figure 9).
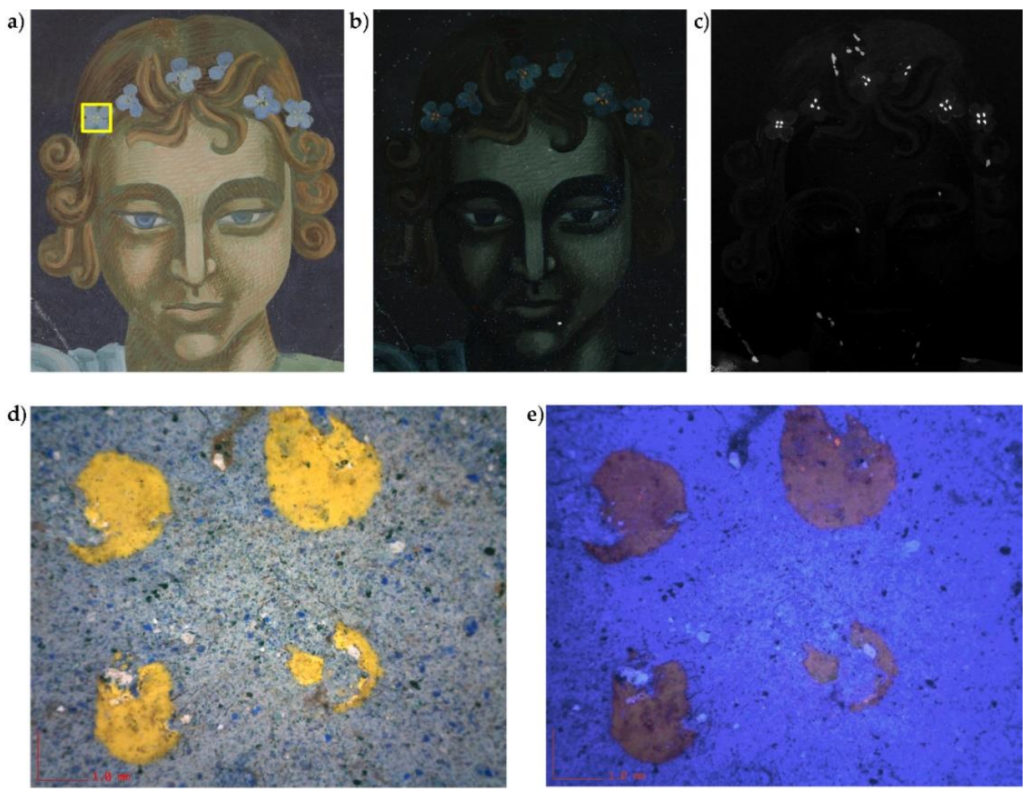

Figure 9. (a) Vis, (b) UVL and (c) VIL images (image size ca. $25 \mathrm{~cm} \times 30 \mathrm{~cm}$ ) of the angel depicting in the Holy family; (d) Vis and (e) UVL images collected by digital microscope (magnification $50 \times$ ) on the area indicated with a yellow square in (a). 
A specific analytical response concerning the characterization of the cadmium yellow pigment widely used by Severini, was provided by Raman investigation of a micro-sample coming from the Saint Nicolas (floral decoration of the Saint's shoe, see Figure 10a). The UVL image of the cross-section obtained for this micro-sample (Figure 10c) promptly reveals particles with strong red-orange luminescence ascribable to a cadmium-based pigment. Raman measurements were focused on these luminescent particles. Following Rosi et al. [27], different Raman laser excitations (488, 514, 633 and $785 \mathrm{~nm}$ ) were used to differentiate the type of CdS-based pigment. However, the Raman spectra obtained (Figure 10d) show that cadmium sulfide emerged exclusively using the $514 \mathrm{~nm}$ laser line (maker bands at ca. 302 and $604 \mathrm{~cm}^{-1}$ ), while the other two lasers used in this work (633 and $785 \mathrm{~nm}$ ) provided only an enhancement of the Raman bands correlated to calcium carbonate (ca. 1085, 712 and $280 \mathrm{~cm}^{-1}$ ) and barium sulfate (ca. 988, 461 and $453 \mathrm{~cm}^{-1}$ ) [28].
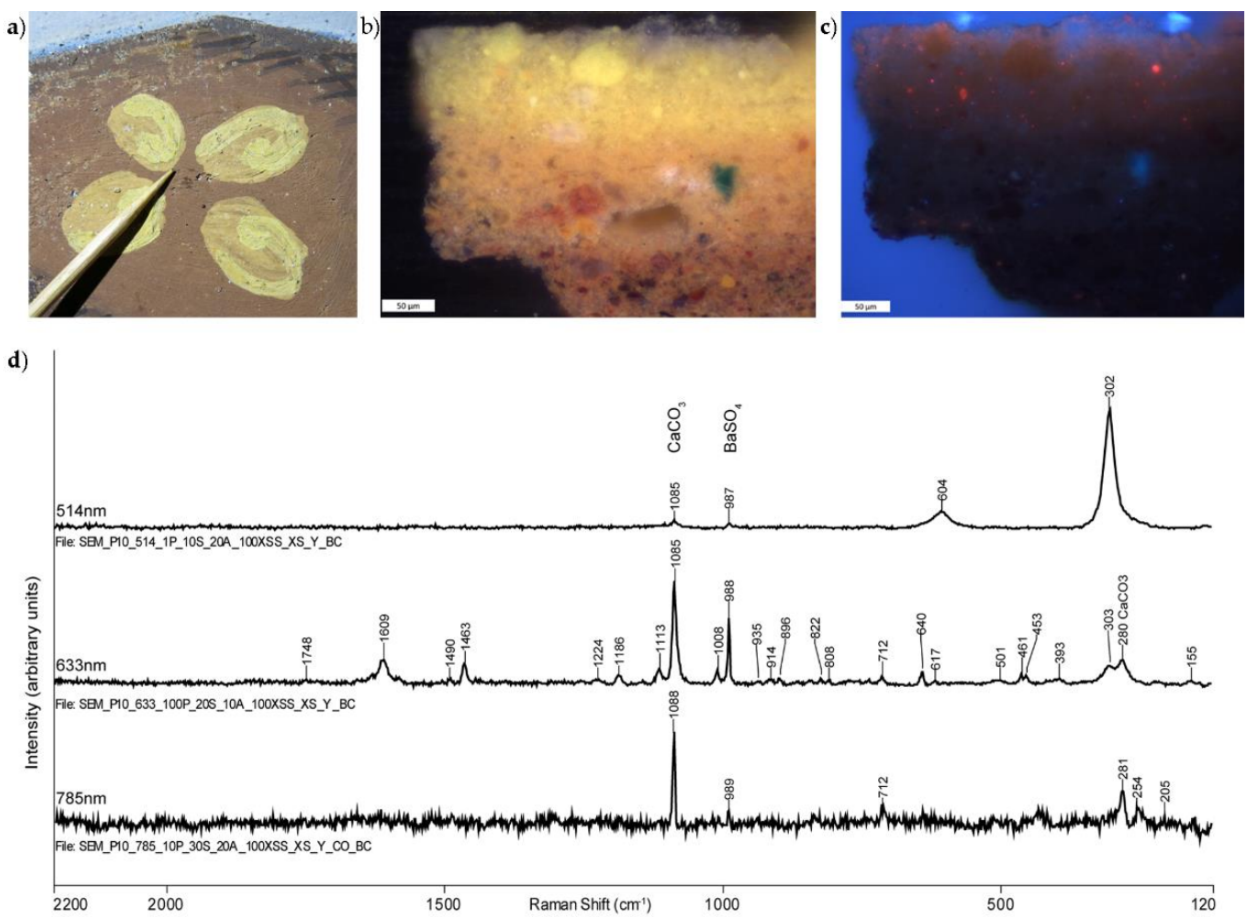

Figure 10. (a) Image of the sampling area (image size ca. $7 \times 8 \mathrm{~cm}$ ) on the floral decoration on the shoe of Saint Nicolas; (b) Vis and (c) UVL optical microscope images of the cross-section of the micro-sample; (d) Raman spectra collected on the cross-section using three different laser excitations (514, 633 and $785 \mathrm{~nm})$.

In all the non-invasive FT-IR spectra collected from these wall paintings (95 spectra in total) the marker bands of the calcium carbonate were promptly recognized, in contrast with the results of the Trinty (47 spectra in total) where gypsum was largely predominant over calcium carbonate everywhere. In addition, the FT-IR maps of the cross-sections obtained for the micro-samples taken in these areas (see the cross-section in Figure 11), showed that calcium carbonate $\left(v_{3}\right.$ antisymmetric stretching of $\mathrm{CO}_{3}{ }^{2-}$ in the IR region between 1471 and $1331 \mathrm{~cm}^{-1}$-Figures 11e and S5) is distributed along the full stratigraphy. This evidence, integrated with the visual examination, confirmed the predominant use of either a fresco, lime-based painting technique, or both. However, several of the FT-IR spectra acquired on the Eucharist and on the figures of the two saints (Saint Nicolas and Saint Sebastian) presented a weak carbonyl band at ca. $1730 \mathrm{~cm}^{-1}$ and possible $\mathrm{CH}$ bands in the range between 3000 and $2700 \mathrm{~cm}^{-1}$. These IR features could be correlated to an organic material possibly used in minimal amounts in or over the paintings that may have altered over time producing metal-oxalate complexes. In some FT-IR spectra (Figure S5), 
indeed, a weak band at ca. $1320 \mathrm{~cm}^{-1}$, ascribable to $v_{\mathrm{s}}(\mathrm{CO})$ vibration of oxalates [29], was recognized.
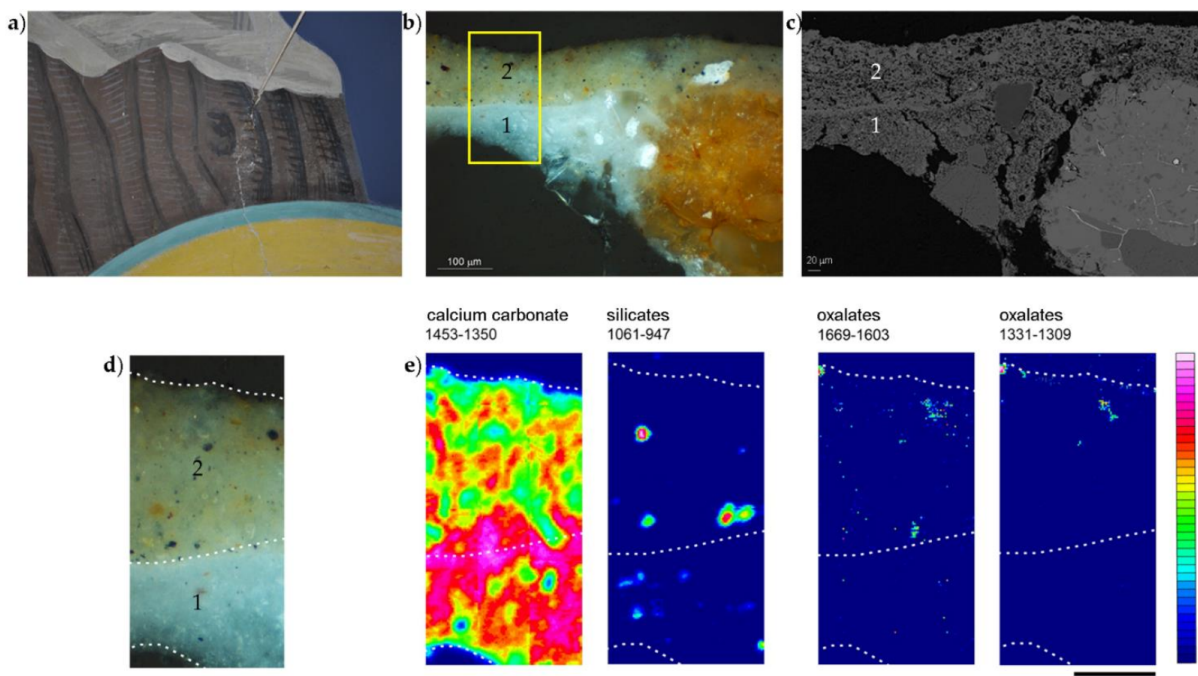

oxalates

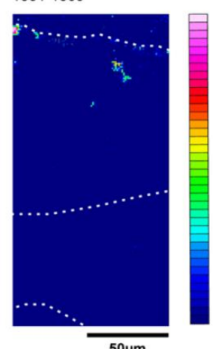

Figure 11. (a) Image of the sampling area (image size ca. $35 \times 20 \mathrm{~cm}$ ) along a fracture in the tree trunk behind the figure of Saint Sebastian; (b) optical microscope and (c) SEM-BSE images of the crosssection of the micro-sample collected in (a); (d) area analyzed by FTIR-FPA imaging (the location is shown in (b) with a yellow rectangle); (e) FTIR-FPA imaging results with integration of the following spectral range: $1453-1350 \mathrm{~cm}^{-1}$ (calcium carbonate); $1061-947 \mathrm{~cm}^{-1}$ (silicates); $1669-1603 \mathrm{~cm}^{-1}$ and $1331-1309 \mathrm{~cm}^{-1}$ (oxalates).

Concerning the detection of non-original materials, only an acrylic resin was found on a glossy retouched area of the Eucharist mural (red/brown cloak of $8^{\text {th }}$ apostle from left).

\section{Discussion}

The analytical results obtained from the study of the wall paintings in the Church of Saint Nicolas de Myre at Semsales summarized in Table 2, provide insights into the painting materials and the techniques used by Severini for his first monumental wall decoration in Switzerland.

Severini started depicting the Trinity in the apse by painting a tempera on an existing "rabitz" plaster, as he reported in his notes [10]. The term "rabitz" is generally used to indicate a substructure made of woven reeds or wire mesh, which supports a gypsum or cement plaster. The analytical investigations of the Trinity have confirmed the presence of a gypsum-based plaster mixed with sand aggregates. However, the "colla" (i.e. the animal glue) described by Severini [10] as part of the "rabitz" mixture was not identified. This layer does not contain any organic material. As clearly revealed by the cross-section analyses, over the gypsum plaster there is a protein-based primer (thickness of ca. $2-3 \mu \mathrm{m}$ ) followed by a lime-based preparatory layer of variable thickness (between 250 and $40 \mu \mathrm{m}$ ) not containing any organic binder. It is possible that Severini started by applying the protein-primer on the gypsum and then the lime-based preparatory layer to level the surface. In his notes, contemporary to the work in Semsales, Severini describes several ways to prepare a "rabitz" wall for painting [9]. These recipes could correspond to textural differences revealed by visual examination. However, the stratigraphy and the materials identified in the cross-sections do not correspond exactly to any of these preparation recipes and an extensive invasive sampling campaign would be necessary to characterize them. Another question relates to the presence of an additional yellow preparatory layer visible in the stratigraphy of the two angels over the Trinity in the upper most portions of the apse, but missing in the samples from the other areas. This layer contains pigments used by the artist elsewhere, but its role and its presence in the lower portion of the mandorla 
remains unclear. Regarding the paint layer, the analyses confirm that the Trinity mural was painted a tempera with a protein-based binder composed of animal glue and possibly casein. Although non-invasive FT-IR investigations identified a lipid component (indicated by the IR ester band at ca. $1740 \mathrm{~cm}^{-1}$ ), the exact nature of this material remains unknown and the results of chromatographic analyses are inconclusive as only a pine resin was identified. A further sampling campaign would be necessary to clarify the nature of this lipid-based material.

Table 2. Summary of the analytical results obtained from the study of Semsales wall paintings.

\begin{tabular}{|c|c|c|c|}
\hline Wall Paintings & Pigments & Organic Materials & Fillers/Extenders \\
\hline Trinity & $\begin{array}{c}\text { Zinc white, } \\
\text { Cadmium yellow, } \\
\text { Cadmium/mercury orange, } \\
\text { Vermilion, } \\
\text { Red/brown/black earths, } \\
\text { Organic red pigment, } \\
\text { Chrome-based greens, } \\
\text { Ultramarine blue, } \\
\text { Ivory black }\end{array}$ & $\begin{array}{l}\text { Animal glue } \\
\text { Casein } \\
\text { Acrylic resin * } \\
\text { Vinyl resin * } \\
\text { Sty/n-BA } \\
\text { copolymer* }\end{array}$ & $\begin{array}{l}\text { Kaolinite } \\
\text { Gypsum }\end{array}$ \\
\hline Eucharist & $\begin{array}{c}\text { Sangiovanni white, } \\
\text { Cadmium yellow, } \\
\text { Yellow/red ochre, } \\
\text { Vermilion, } \\
\text { Chrome-based greens, } \\
\text { Green/brown/black earths, } \\
\text { Ultramarine blue, } \\
\text { Cobalt blue, } \\
\text { Ivory black }\end{array}$ & $\begin{array}{c}\text { Oxalates } \\
\text { Acrylic resin * }\end{array}$ & $\begin{array}{l}\text { Kaolinite } \\
\text { Gypsum }\end{array}$ \\
\hline St. Nicolas & $\begin{array}{c}\text { Sangiovanni white, } \\
\text { Cadmium yellow, } \\
\text { Yellow/red ochre, } \\
\text { Alizarine lake, } \\
\text { Vermilion, } \\
\text { Chrome-based greens, } \\
\text { Green/brown/black earths, } \\
\text { Ultramarine blue, } \\
\text { Cobalt blue }\end{array}$ & Oxalates & $\begin{array}{l}\text { Kaolinite } \\
\text { Gypsum }\end{array}$ \\
\hline St. Sebastian & $\begin{array}{c}\text { Sangiovanni white, } \\
\text { Cadmium yellow, } \\
\text { Yellow/red ochre, } \\
\text { Chrome-based greens, } \\
\text { Green/brown/black earths, } \\
\text { Ultramarine blue, } \\
\text { Cobalt blue }\end{array}$ & Oxalates & Kaolinite \\
\hline $\begin{array}{l}\text { Virgin and Child } \\
\text { Holy family }\end{array}$ & $\begin{array}{c}\text { Sangiovanni white, } \\
\text { Cadmium yellow, } \\
\text { Yellow/red ochre, } \\
\text { Vermilion } \\
\text { (only in Virgin and Child), } \\
\text { Chrome-based greens, } \\
\text { Green/brown/black earths, } \\
\text { Ultramarine blue, } \\
\text { Cobalt blue, } \\
\text { Ivory black } \\
\text { Possible alizarine lake } \\
\text { (only in Holy family) }\end{array}$ & Oxalates & $\begin{array}{c}\text { Kaolinite } \\
\text { Gypsum } \\
\text { (only in Holy family) }\end{array}$ \\
\hline
\end{tabular}


For the other figurative wall paintings (Eucharist, Saint Nicolas, Saint Sebastian, Virgin and Child and Holy family), Severini used the traditional a fresco and lime-based technique experimented for the first time only a few years earlier in the castle of Montegufoni in Tuscany (1921-1922) [30]. The non-invasive infrared analyses supported and integrated by the study of the cross-sections proved the use of lime as binder. However, the detection of oxalates and weak carbonyl and $\mathrm{CH}$ bands indicate a possible addition of small amounts of organic material.

The range of pigments identified in the Semsales murals reveals that Severini combined traditional a fresco pigments (e.g., iron-based pigments) with modern ones, i.e., zinc white (only in the Trinity), cobalt blue, synthetic ultramarine blue, synthetic alizarin lake, chrome-based greens and cadmium-based yellow and orange pigments (see Table 2 for the complete list). In particular, the cadmium-based pigments are readily identified by technical photography thanks to their characteristic luminescence revealed in both UVL and VIL images [31].

Analytically, the use of modern pigments in the 20th century has been widely explored in easel paintings [32-36], while their application in wall paintings is less known [37-39]. In addition, Semsales is an exceptional example of extensive use of cadmium-based pigments not commonly found in wall paintings, especially the cadmium/mercury sulphide type [40] that probably corresponds to the cadmium orange purchased for the church decoration (see Table S1).

The analytical data are generally in accordance with the results of the archival research. For example, the pigments identified and the casein are listed in the invoices of materials purchased for the church decoration (see Table S1). However, there are some incongruences, and some questions remain open. Notably, the use of potassium silicate, listed among the materials purchased for the decoration of the church and mentioned by Severini in his writings for the silicate paint [41], was not analytically identified with the methods used in any of the wall paintings studied.

This paper is an example of the relevance of the analytical approach that, correlated with the conservator's observations, provides an objective support for the technical study and the interpretation of the historical and archival sources.

The project focused on the study of Severini's wall paintings in Switzerland is ongoing and the findings achieved for the Semsales church represent the basis for the examination of the other religious murals painted by the artist in later years. Currently, the analytical results acquired in Semsales are archived, organized and linked to other information in a specific data management system [42] to be provided in an open access format in future.

Supplementary Materials: The following are available online at https:/ / www.mdpi.com/article/10 $.3390 /$ app11199161/s1. Figure S1. XRF spectra (a and c) collected from a white area on the forehead of the central figure of the Trinity (b) and a yellow area of the halo (d). Figure S2. XRF spectra (a and c) collected from an orange area on the wing of an angel of the vault (b) and a red/brown area on the lips of the central figure of the Trinity (d). Figure S3. (a) Optical microscope image of the sample shown in Figure 4; (b) FTIR-FPA imaging results corresponding to the spectral range between 1695 and $1615 \mathrm{~cm}^{-1}$ (amide I/protein) with indication (black circle) of the acquisition point of the IR spectrum shown in c. In the spectrum are visible the amide bands at ca. 1643 (amide I) and $1531 \mathrm{~cm}^{-1}$ (amide II), the signals of the ivory black $\left(2012\right.$ and $1030 \mathrm{~cm}^{-1}$ ), the calcium carbonate marker band at $1417 \mathrm{~cm}^{-1}$ and the signals of the casting resin at ca. 1507,1246 and $1181 \mathrm{~cm}^{-1}$. Figure S4. (a) SEM-BSE image of the cross-section of the sample shown in Figure 7 with indication of the acquisition point of the SEM-EDS spectra reported in d (1) and e (2); (b) optical microscope image of the sample corresponding to the white square marked in a; (c) FTIR-FPA imaging results of the calcium carbonate distribution. Figure S5. (a) Optical microscope image of the sample shown in Figure 11; (b) FTIR-FPA imaging results corresponding to the spectral ranges between 1453 and $1350 \mathrm{~cm}^{-1}$ (calcium carbonate) and $1331-1309 \mathrm{~cm}^{-1}$ (oxalates) with indication (white circles) of the acquisition points of the IR spectra shown in c (1) and d (2). Spectrum in (c) shows the calcium carbonate marker bands $\left(1396,1796\right.$ and $\left.2512 \mathrm{~cm}^{-1}\right)$, while the oxalate marker band at ca. $1320 \mathrm{~cm}^{-1}$ is 
weakly visible in the spectrum reported in d. Table S1: Transcription of paintings materials purchased between 1924 and 1926 for the decoration of the Saint Nicolas de Myre Church at Semsales.

Author Contributions: Conceptualization, P.M. and F.P.; methodology, P.M. and F.P.; investigation P.M., F.P., S.Z., O.C., N.G. and P.I.; writing-original draft preparation P.M.; writing-review and editing P.M. and F.P.; supervision and project administration, F.P. All authors have read and agreed to the published version of the manuscript.

Funding: This research was funded by the Swiss National Science Foundation, grant number 179364 (http:/ / p3.snf.ch/project-179364, last access: 30 September 2021) and by the University of Applied Sciences and Arts of Southern Switzerland (SUPSI).

Institutional Review Board Statement: Not applicable.

Informed Consent Statement: Not applicable.

Data Availability Statement: The authors confirm that the data supporting the findings of this study are available within the article and in the Supplementary Materials. All the raw data is archived in digital form on the server of the University of Applied Sciences and Arts of Southern Switzerland (SUPSI). Raw data can be obtained through the corresponding authors (P.M., F.P.) upon request.

Acknowledgments: The authors are grateful to all the other members SNSF project: Margherita d'Ayala Valva (art historian), Maria Rosa Lanfranchi (senior conservator), Stefania Luppichini (conservator), Dave Lüthi (art historian), Camille Noverraz (art historian), Jacopo Russo (architect) and Nadim C. Sherrer (scientist). In particular, Camille Noverraz is gratefully acknowledged for her valuable archival research and for the support provided in the transcription of paintings materials purchased for the Semsales decoration. Thanks to the company Archéotech SA for the acquisition of the orthophotos shown in the paper. The authors would like to acknowledge Francesca Sabatini, Jacopo La Nasa, Francesca Modugno and Maria Perla Colombini of the University of Pisa (Italy), Department of Chemistry and Industrial Chemistry, for the chromatographic analyses. The investigations were guided and enriched by the fundamental unpublished manuscript by Severini generously provided by Professor Piero Pacini during a visit in his home-archive in Florence. Pacini was a close friend of Severini's family and we sincerely thank him for his continuous support and for sharing so much information from his archive. We acknowledge the help of M. Gérard Curty, President of the Conseil de paroisse at Semsales, who kindly supported our team for all necessities and provided access to the Church archives. Romana Brunori Severini, daughter of Gino, is acknowledged for her complete support and insights throughout the project. Finally, the authors are grateful to the reviewers for their valuable comments and suggestions that helped in improving the quality of this article.

Conflicts of Interest: The authors declare no conflict of interest.

\section{References}

1. Cingria, A. Histoire du Groupe Romand de la Société Saint-Luc. L'Art Sacré 1935, 6, 26-27.

2. Carey, E. Nova et Vetera et l'art religieux catholique en Suisse romande. In 19-39, La Suisse Romande Entre Les Deux Guerres; Collectif de Recherches de l'Université et Musées Lausannois, Payot: Lausanne, Switzerland, 1986; pp. 92-105.

3. Severini, G. La vita di un Pittore; Abscondita: Milano, Italy, 2008.

4. Gino Severini in Switzerland: Mural Paintings and Catholic Art Revival of the Groupe de Saint Luc. Available online: http: / /p3.snf.ch/project-179364 (accessed on 3 August 2021).

5. St. Luc Project. Available online: https://stluc.ch/ (accessed on 3 August 2021).

6. Iazurlo, P.; Piqué, F.; Noverraz, C.; D'Ayala Valva, M. The modern Catholic wall paintings by Gino Severini in Switzerland: An integrated technical study. In Proceedings of the ICOM-CC 19th Triennial Conference Preprints, Beijing, China, 17-21 May 2021; Bridgland, J., Ed.; International Council of Museums: Paris, France, 2021.

7. D'Ayala Valva, M.; Noverraz, C. Gino Severini's «besoin de s'humaniser»: Christian mural painting in Switzerland as a path towards synthesis, 1923-1947. Studi Memofonte 2021, submitted.

8. Pacini, P. Gino Severini a Semsales. Un rinnovatore dell'arte sacra colto ed 'eretico'. Crit. D'arte 2012, 74, 47-66.

9. Iazurlo, P.; Moretti, P.; Piqué, F. Gino Severini in Switzerland: A technical study of the wall paintings of St. Nicolas de Myre in Semsales. Stud. Conserv. 2021, 1-22. [CrossRef]

10. Severini, G. Transcending Boundaries: Integrated Approaches to Conservation. In Proceedings of the 19th ICOM-CC Virtual Triennial Conference, Beijing, China, 17-21 May 2021.

11. Piqué, F.; Verri, G. Project Report: Organic Materials in Wall Paintings. The Getty Conservation Institute; Los Angeles, CA, USA. 2015. Available online: https://www.getty.edu/conservation/our_projects/science/omwp/ (accessed on 3 August 2021). 
12. Radin, G. Il carteggio Gino Severini Jacques Maritain (1923-1966); Olschki, L.S., Ed.; Museo di Arte Moderna e Contemporanea di Trento e Rovereto: Firenze, Italy, 2011.

13. D'Ayala Valva, M. Dal Frammento al Trattato. Gino Severini: Trascrizioni, Ricette e Note Tecniche, Progetti di Opere; Della Normale: Pisa, Italy, 2018.

14. Dyer, J.; Verri, G.; Cupitt, J. Multispectral Imaging in Reflectance and Photo-Induced Luminescence Modes: A User Manual; British Museum: London, UK, 2013.

15. Cosentino, A. Identification of pigments by multispectral imaging; a flowchart method. Herit. Sci. 2014, 2, 8. [CrossRef]

16. Fiedler, I.; Bayard, M. Cadmium Yellows, Oranges, and Reds. In Artist's Pigments: A Handbook of Their History and Characteristics; Feller, R.L., Ed.; National Gallery of Art, Washington Archetype Publications: London, UK, 1986; Volume 1, pp. 65-108.

17. Zumbuehl, S.; Scherrer, N.C.; Berger, A.; Eggenberger, U. Early Viridian Pigment Composition Characterization of a (Hydrated) Chromium Oxide Borate Pigment. Stud. Conserv. 2009, 54, 149-159. [CrossRef]

18. Verri, G.; Clementi, C.; Comelli, D.; Cather, S.; Piqué, F. Correction of ultraviolet-induced fluorescence spectra for the ex-amination of polychromy. Appl. Spectrosc. 2008, 62, 1295-1302. [CrossRef]

19. Rosi, F.; Daveri, A.; Moretti, P.; Brunetti, B.G.; Miliani, C. Interpretation of mid and near-infrared reflection properties of synthetic polymer paints for the non-invasive assessment of binding media in twentieth-century pictorial artworks. Microchem. J. 2016, 124, 898-908. [CrossRef]

20. Rosi, F.; Daveri, A.; Miliani, C.; Verri, G.; Benedetti, P.; Piqué, F.; Brunetti, B.G.; Sgamellotti, A. Non-Invasive identification of organic materials in wall paintings by fiber optic reflectance infrared spectroscopy: A statistical multivariate approach. Anal. Bioanal. Chem. 2009, 395, 2097-2106. [CrossRef]

21. Vagnini, M.; Miliani, C.; Cartechini, L.; Rocchi, P.; Brunetti, B.G.; Sgamellotti, A. FT-NIR spectroscopy for non-invasive identification of natural polymers and resins in easel paintings. Anal. Bioanal. Chem. 2009, 395, 2107-2118. [CrossRef]

22. Tomasini, E.; Siracusano, G.; Maier, M. Spectroscopic, morphological and chemical characterization of historic pigments based on carbon. Paths for the identification of an artistic pigment. Microchem. J. 2012, 102, 28-37. [CrossRef]

23. Sabatini, F.; La Nasa, J.; Modugno, F.; Colombini, M.P. Unpublished scientific report for SUPSI by Dipartimento di Chimica e Chimica Industriale, Università di Pisa, Italy, 2021.

24. Regazzoni, L.; Cavallo, G.; Biondelli, D.; Gilardi, J. Microscopic Analysis of Wall Painting Techniques: Laboratory Replicas and Romanesque Case Studies in Southern Switzerland. Stud. Conserv. 2017, 63, 326-341. [CrossRef]

25. Schulte, F.; Brzezinka, K.-W.; Lutzenberger, K.; Stege, H.; Panne, U. Raman spectroscopy of synthetic organic pigments used in 20th century works of art. J. Raman Spectrosc. 2008, 39, 1455-1463. [CrossRef]

26. Scherrer, N.C.; Zumbühl, S.; Delavy, F.; Fritsch, A.; Kuehnen, R. Synthetic organic pigments of the 20th and 21st century relevant to artist's paints: Raman spectra reference collection. Spectrochim. Acta A 2009, 73, 505-524. [CrossRef] [PubMed]

27. Rosi, F.; Grazia, C.; Gabrieli, F.; Romani, A.; Paolantoni, M.; Vivani, R.; Brunetti, B.G.; Colomban, P.; Miliani, C. UV-Vis-NIR and micro Raman spectroscopies for the non destructive identification of Cd1-xZnxS solid solutions in cadmium yellow pigments. Microchem. J. 2016, 124, 856-867. [CrossRef]

28. Bell, I.M.; Clark, R.J.; Gibbs, P.J. Raman spectroscopic library of natural and synthetic pigments (pre- $\approx 1850$ AD). Spectrochim. Acta A 1997, 53, 2159-2179. [CrossRef]

29. Monico, L.; Rosi, F.; Miliani, C.; Daveri, A.; Brunetti, B.G. Non-Invasive identification of metal-oxalate complexes on poly-chrome artwork surfaces by reflection mid-infrared spectroscopy. Spectrochim. Acta A 2013, 116, 270-280. [CrossRef]

30. Alberti, M. Gli affreschi di Gino Severini nel castello di Montegufoni e il mito novecentesco della Commedia dell'arte. Commedia dell'arte. Annu. Int. 2011, IV, 105-122.

31. Daveri, A.; Vagnini, M.; Nucera, F.; Azzarelli, M.; Romani, A.; Clementi, C. Visible-Induced luminescence imaging: A user-friendly method based on a system of interchangeable and tunable LED light sources. Microchem. J. 2016, 125, 130-141. [CrossRef]

32. Izzo, F.C.; Capogrosso, V.; Gironda, M.; Alberti, R.; Mazzei, C.; Nodari, L.; Gambirasi, A.; Zendri, E.; Nevin, A. Multi-Analytical non-invasive study of modern yellow paints from postwar Italian paintings from the International Gallery of Modern Art Cà Pesaro, Venice. X-Ray Spectrom. 2015, 44, 296-304. [CrossRef]

33. Martins, A.; Albertson, C.; McGlinchey, C.; Dik, J. Piet Mondrian's Broadway Boogie Woogie: Non invasive analysis using macro X-ray fluorescence mapping (MA-XRF) and multivariate curve resolution-alternating least square (MCR-ALS). Herit. Sci. 2016, 4, 418. [CrossRef]

34. Favero, P.A.; Mass, J.; Delaney, J.K.; Woll, A.R.; Hull, A.M.; Dooley, K.A.; Finnefrock, A.C. Reflectance imaging spectroscopy and synchrotron radiation X-ray fluorescence mapping used in a technical study of The Blue Room by Pablo Picasso. Herit. Sci. 2017, 5, 26. [CrossRef]

35. Rosi, F.; Grazia, C.; Fontana, R.; Gabrieli, F.; Buemi, L.P.; Pampaloni, E.; Romani, A.; Stringari, C.; Miliani, C. Disclosing Jackson Pollock's palette in Alchemy (1947) by non-invasive spectroscopies. Herit. Sci. 2016, 4, 10. [CrossRef]

36. Bochicchio, L.; Moretti, P.; Chieli, A.; Romani, A.; Ruberto, C.; Castelli, L.; Brunetti, B.G.; Sgamellotti, A.; Cartechini, L. "Art is Not Science": A Study of Materials and Techniques in Five of Enrico Baj's Nuclear Paintings. In Science and Art: The Contemporary Painted Surface; Sgamellotti, A., Brunetti, B.G., Miliani, C., Eds.; Royal Society of Chemistry: London, UK, 2020; pp. 139-168.

37. Piqué, F.; Derrick, M.; Parker, A.; Schilling, M.; Scott, D. Original Technique of the Mural America Tropical by David Alfaro Siqueiros. MRS Online Proc. Libr. Arch. 1995, 352, 365-371. [CrossRef] 
38. Moretti, P.; Gallegos, D.; Marte, F.; Brunetti, B.; Sgamellotti, A.; Miliani, C. Materials and Techniques of Twentieth Century Argentinean Murals. Procedia Chem. 2013, 8, 221-230. [CrossRef]

39. Izzo, F.C.; Falchi, L.; Zendri, E.; Biscotin, G. A study on materials and painting techniques of 1930s Italian mural paintings: Two cases by Mario Sironi and Edmondo Bacci in Venice. In Conservation Issues in Modern and Contemporary Murals; Cambridge Scholar Publishing: Newcastle upon Tyne, UK, 2015; pp. 35-51.

40. Kovalev, I.; Costa, M.; Valadas, S.; Cardoso, A.; Candeias, A.; Gil, M. Exploratory Analytical Study of a 20th century Portuguese Mural Painting by Julio Resende (1917-2011). Int. J. Conserv. Sci. 2020, 11, 627-638.

41. Severini, G. Technique pour peindre sur facades. Bull. de l'Effort Moderne 1925, 18-19, 6-7.

42. Russo, J.; Luppichini, S.; Stefani, C.; Piqué, F. The study of Severini's wall paintings in Switzerland: How to manage hetero-geneity of data and team members? IOP Conf. Ser. Mater. Sci. Eng. 2020, 949, 1-8. [CrossRef] 